\title{
Sesquiterpenes and Other Constituents from Dendranthema zawadskii var. latilobum
}

\author{
Hyun Jung Shin, ${ }^{a}$ So Young Lee, ${ }^{a}$ Ju Sun Kim, ${ }^{a}$ Sanghyun Lee, ${ }^{b}$ Ran Joo Choi, ${ }^{a}$ \\ Ha Sook Chung, ${ }^{c}$ Yeong Shik Kim, ${ }^{a}$ and Sam Sik Kang*,a \\ ${ }^{a}$ Natural Products Research Institute and College of Pharmacy, Seoul National University; Seoul 151-742, Korea: \\ ${ }^{b}$ Department of Integrative Plant Science, College of Natural Science, Chung-Ang University; Anseong 456-756, \\ Korea: and ${ }^{c}$ Department of Foods and Nutrition, College of Natural Sciences, Duksung Women's University; Seoul \\ 132-714, Korea. $\quad$ Received September 27, 2011; accepted December 6, 2011; published online December 13, 2011
}

Six new germacranolides, zawadskinolides $\mathrm{A}-\mathrm{F}(1-6)$, and a new eudesmane glucoside, chrysantiloboside (7) were isolated from the aerial parts of Dendranthema zawadskii var. latilobum, along with thirteen known constituents. Their structures were elucidated by means of spectroscopic evidence. Bioassay showed that flavonoids such as apigenin (9), (-)-eriodictyol (10) and nepetin (12), as well as the sesquiterpene lactone, zawadskinolide F (6), inhibited nitric oxide (NO) production in lipopolysaccharide (LPS)-stimulated RAW 264.7 macrophage cells with $\mathrm{IC}_{50}$ values of $66.15,132.55,35.44$, and $91.32 \mu \mathrm{M}$, respectively.

Key words Dendranthema zawadskii var. latilobum; Asteraceae; germacranolide; eudesmane glucoside; nitric oxide inhibition

The genus Dendranthema (Asteraceae) is represented by 10 wild and cultivated species in Korea. ${ }^{1)}$ The aerial parts of Dendranthema zawadskii (HERBICH) TzVelev var. latilobum (MaXim.) Kitam. (syn. Chrysanthemum zawadskii Herbich var. latilobum КітAм.) have been used in traditional folk medicine for the treatment of pneumonia, bronchitis, cough, common cold, pharyngitis, gastroenteric disorders, and female diseases such as menstrual abnormalities and placental complications. ${ }^{2)}$ Previous phytochemical investigations on this plant resulted in the isolation of polyacetylenes, ${ }^{3)}$ sesquiterpene lactones, ${ }^{4)}$ flavonoids and phenolics, ${ }^{5-7)}$ essential oils, ${ }^{8)}$ and others. ${ }^{9)}$ These isolates have a variety of biological functions such as antifungal, ${ }^{3)}$ cytotoxic, $^{10)}$ antimicrobial ${ }^{5)}$ and antibiotic ${ }^{4)}$ effects, nitric oxide and cholesterol acyltransferase inhibition, ${ }^{11)}$ farnesyl protein transferase (FPTase) inhibition, ${ }^{12)}$ and quinone reductase modulation. ${ }^{13)}$ In addition, the $70 \%$ EtOH extract and its hexane-soluble fraction were reported to strongly inhibit inducible nitric oxide synthase (iNOS) and cyclooxygenase-2 (COX-2) activity. ${ }^{14)}$ In the course of our studies on the constituents of the $\mathrm{MeOH}$ extract of the aerial parts of D. zawadskii var. latilobum, six new sesquiterpene lactones, zawadskinolides A-F (1-6), and a new eudesmane glucoside, chrysantiloboside (7), together with thirteen known compounds were isolated. Since $\mathrm{NO}$ and prostaglandin $\mathrm{E}_{2}$ are considered the major inflammatory mediators and in keeping with the traditional medical applications of this herb ${ }^{2)}$ and the previous report on its anti-inflammatory activity, ${ }^{14)}$ the isolates were evaluated for their inhibitory effects on nitric oxide (NO) production in lipopolysaccharide (LPS)-stimulated RAW 264.7 macrophage cells. In this paper, we report the isolation, structural elucidation and biological evaluation of these compounds.

\section{Results and Discussion}

Dried aerial parts of D. zawadskii var. latilobum were extracted with $\mathrm{MeOH}$ and then fractionated with hexane, $\mathrm{CH}_{2} \mathrm{Cl}_{2}$, EtOAc, $n$-BuOH and water. By combined chromatographic separations of these extracts, seven new and thirteen known compounds were isolated. Their structures were elucidated using physicochemical and spectroscopic methods.
The IR spectrum of $\mathbf{1}$ displayed absorption bands diagnostic of an $\mathrm{OH}$ group $\left(3470,3386 \mathrm{~cm}^{-1}\right), \gamma$-lactone $\left(1755 \mathrm{~cm}^{-1}\right)$, acetate $\left(1740,1238 \mathrm{~cm}^{-1}\right)$, and olefinic $\left(1640 \mathrm{~cm}^{-1}\right)$ functionalites. The high resolution-electron ionization (HR-EI) MS showed a molecular ion peak at $m / z 324.1560[\mathrm{M}]^{+}$, suggestive of a molecular formula of $\mathrm{C}_{17} \mathrm{H}_{24} \mathrm{O}_{6}$ (Calcd for $\mathrm{C}_{17} \mathrm{H}_{24} \mathrm{O}_{6}$ 324.1573) and six degrees of unsaturation. The ${ }^{1} \mathrm{H}-\mathrm{NMR}$ spectrum exhibited signals due to a secondary methyl at $\delta_{\mathrm{H}} 1.24$ $(3 \mathrm{H}, \mathrm{d}, J=7.8 \mathrm{~Hz})$, vinyl methyl protons at $\delta_{\mathrm{H}} 1.65(3 \mathrm{H}, \mathrm{s})$, an acetoxyl methyl at $\delta_{\mathrm{H}} 2.10(3 \mathrm{H}, \mathrm{s})$, two oxygenated methylene protons at $\delta_{\mathrm{H}} 3.98(2 \mathrm{H}$, brd, $J=0.6 \mathrm{~Hz})$, two olefinic protons at $\delta_{\mathrm{H}} 5.35(1 \mathrm{H}$, brd, $J=10.3 \mathrm{~Hz})$ and $5.24(1 \mathrm{H}$, brdd, $J=6.5$, $9.8 \mathrm{~Hz})$, and three oxygenated methine protons at $\delta_{\mathrm{H}} 4.88(1 \mathrm{H}$, $\mathrm{dd}, J=1.2,11.1 \mathrm{~Hz}), 5.47(1 \mathrm{H}, \mathrm{dd}, J=3.3,4.1 \mathrm{~Hz})$ and $5.64(1 \mathrm{H}$, $\mathrm{t}, J=10.3 \mathrm{~Hz})$. The ${ }^{13} \mathrm{C}-\mathrm{NMR}$ and distortionless enhancement by polarization transfer (DEPT) spectra showed a secondary methyl group at $\delta_{\mathrm{C}} 11.3$; a tertiary methyl at $\delta_{\mathrm{C}} 17.3$; an acetoxyl group at $\delta_{\mathrm{C}} 21.1$ and 171.1; two methylene carbons at $\delta_{\mathrm{C}}$ 34.0 and 26.7; three oxygenated methine carbons at $\delta_{\mathrm{C}} 64.7$, 72.4 and 81.8; an oxygenated methylene carbon at $\delta_{\mathrm{C}} 65.5$; two methine carbons at $\delta_{\mathrm{C}} 43.4$ and 40.4 ; four olefinic carbons at $\delta_{\mathrm{C}} 140.9,126.8,139.9$ and 126.1; and a lactone carbon at $\delta_{\mathrm{C}}$ 182.0. The ${ }^{1} \mathrm{H}-{ }^{1} \mathrm{H}$ correlation spectroscopy (COSY) spectrum (Fig. 2) allowed identification of two spin systems in the structure $\left[\mathrm{A} ; \boldsymbol{\square}=\mathrm{CH}-\mathrm{CH}(\mathrm{O})-\mathrm{CH}\left(\mathrm{CH}(\boldsymbol{\square})-\mathrm{CH}_{3}\right)-\mathrm{CH}_{2}-\mathrm{CH}=\mathbf{\square}\right.$, $\mathrm{B}$; $-\mathrm{CH}(\mathrm{OH})-\mathrm{CH}_{2}-\mathrm{CH}(\mathrm{O})-\boldsymbol{\square}$; The symbol $\boldsymbol{\square}$ represents quaternary carbon], from which a complete molecule could be built by long range correlation in ${ }^{1} \mathrm{H}-{ }^{1} \mathrm{H}$ COSY spectrum and heteronuclear multiple bond correlation (HMBC) experiments. The two olefinic protons resonating at $\delta_{\mathrm{H}} 5.35(1 \mathrm{H}$, brd, $J=10.3 \mathrm{~Hz})$ and $5.24(1 \mathrm{H}$, brdd, $J=6.5,9.8 \mathrm{~Hz})$ exhibited allylic correlations with two hydroxymethyl hydrogens at $\delta_{\mathrm{H}}$ $3.98(2 \mathrm{H}$, brd, $J=0.6 \mathrm{~Hz})$ and a vinyl methyl at $\delta_{\mathrm{H}} 1.65(3 \mathrm{H}$, s), respectively, in the ${ }^{1} \mathrm{H}-{ }^{1} \mathrm{H}$ COSY spectrum, which in turn correlated with $\mathrm{C}-3, \mathrm{C}-4$ and $\mathrm{C}-5$ and $\mathrm{C}-1, \mathrm{C}-9$ and $\mathrm{C}-10$, respectively, implying that partial structures $\mathrm{A}$ and $\mathrm{B}$ could only be linked as a germacranolide skeleton with a hydroxymethyl group bound to $\mathrm{C}-4$. Furthermore, HMBC correlations (Fig. 2) for H-5 to C-3, C-4, C-15, and C-7, H-9 to C-8, C-14, $\mathrm{C}-1$, and $\mathrm{H}-6$ to $\mathrm{C}-4$ and $\mathrm{C}-7$ supported the location of two 
hydroxyl groups at $\mathrm{C}-1$ and $\mathrm{C}-3$, a hydroxymethyl group at $\mathrm{C}-4$, and the $\gamma$-lactone moiety at C-6 and C-7. An acetoxyl group was attached at $\mathrm{C}-3$ by HMBC correlation of $\mathrm{H}-3$ with an acetoxyl $\mathrm{CO}$. The coupling constants across the protons at positions H-5-H-7 $\left(J_{5,6}=J_{6,7}=10.3 \mathrm{~Hz}\right)$ were equivalent to the literature values for a rare, naturally occurring cis- $\Delta^{4,5}$, cis$\Delta^{9,10}$-germacradiene-trans-12,6-olide. ${ }^{15-17)}$ The relative stereo-<smiles>CC(=O)O[C@H]1C[C@@H](O)/C(C)=C\C[C@H]2[C@H](C)C(=O)O[C@H]2/C=C\1CO</smiles>

1

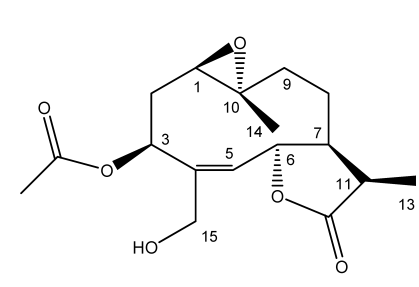

3

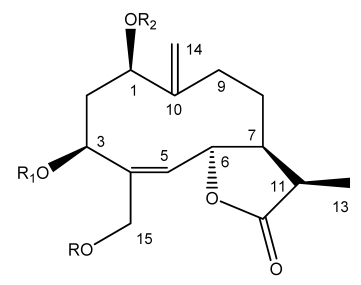

$$
\begin{aligned}
& 4 \quad \mathrm{R}=\mathrm{R}_{1}=\mathrm{R}_{2}=\mathrm{H} \\
& \text { 4a } \quad R=R_{1}=R_{2}=A c \\
& 5 \quad \mathrm{R}=\mathrm{AC} \quad \mathrm{R}_{1}=\mathrm{R}_{2}=\mathrm{H} \\
& 6 R_{1}=A C \quad R=R_{2}=H
\end{aligned}
$$

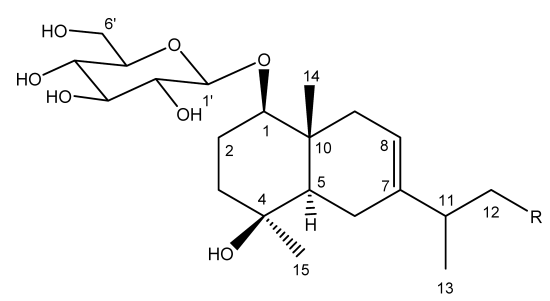

$$
\begin{array}{ll}
7 & \mathrm{R}=\mathrm{OH} \\
8 & \mathrm{R}=\mathrm{H}
\end{array}
$$

Fig. 1. Sesquiterpene Lactones and Sesquiterpene Glucosides from $D$. zawadskii var. latilobum chemistry of $\mathbf{1}$ was determined by comparison of the spectral data of 1 with those recorded for other known cis,cis-dienetype sesquiterpene lactones such as eupacunin, eupacunolin and eurecurvin, ${ }^{15-17)}$ as well as from the nuclear Overhauser effect spectroscopy (NOESY) spectrum (Fig. 2). The coupling constants of $\mathrm{H}-1$ (dd, $J=1.2,11.1 \mathrm{~Hz})$ and $\mathrm{H}-3$ (dd, $J=3.3$, $4.1 \mathrm{~Hz}$ ) and the nuclear Overhauser effect (NOE) correlations of $\mathrm{H}-1 / \mathrm{H}-6, \mathrm{H}-3 / \mathrm{H}-15, \mathrm{H}-5 / \mathrm{H}-7$, and $\mathrm{H}-5 / \mathrm{H}-15$ indicated $1 \alpha, 3 \beta$ orientations for the 1-hydroxyl and 3-acetoxyl groups. ${ }^{16,17)}$ The NOE correlations between $\mathrm{H}-5$ and $\mathrm{H}-15$ and $\mathrm{H}-7$, between $\mathrm{H}-15$ and $\mathrm{H}-14, \mathrm{H}-5$ and $\mathrm{H}-3$, between $\mathrm{H}-15$ and $\mathrm{H}-7$ and $\mathrm{H}-11$, and between $\mathrm{H}-9$ and $\mathrm{H}-14$ and $\mathrm{H}-7$ suggested that the $\mathrm{C}-4$, C-5 and C-9, C-10 bonds are essentially parallel, with the 14-methyl and 15-hydroxymethylene carbons below the ring as in eurecurvin. ${ }^{16)}$ The $Z$-configuration of $\Delta^{4}$ - and $\Delta^{9}$-double bonds was confirmed by the NOE correlations between H-5 and $\mathrm{H}-7$ and $\mathrm{H}-15$ and between $\mathrm{H}-9$ and $\mathrm{H}-7$ and $\mathrm{H}-14$. The chemical shifts and the values of coupling constants of $\mathrm{H}-13$ at $\delta_{\mathrm{H}} 1.24(\mathrm{~d}, J=7.8 \mathrm{~Hz})$ and $\mathrm{H}-11$ at $\delta_{\mathrm{H}} 2.70(\mathrm{dq}, J=7.9,7.8 \mathrm{~Hz})^{18)}$ and the chemical shift of $\mathrm{C}-13$ at $\delta_{\mathrm{C}} 11.3,{ }^{19,20)}$ as well as the NOE correlation of H-7 and H-11, supported that both H-7 and $\mathrm{H}-11$ were in the cis-configuration relative to each other. Therefore, compound $\mathbf{1}$ was identified as $3 \beta$-acetoxy- $1 \alpha, 15$ dihydroxy-germacra-4Z,9Z-dien- $6 \beta, 7 \alpha, 11 \alpha H$-12,6-olide and named zawadskinolide $\mathrm{A}$.

Compound 2 was obtained as a gum and its molecular formula was determined as $\mathrm{C}_{17} \mathrm{H}_{24} \mathrm{O}_{5}$ by HR-EI-MS at $\mathrm{m} / \mathrm{z}$ 308.1630 (Calcd for $\mathrm{C}_{17} \mathrm{H}_{24} \mathrm{O}_{5} 308.1624$ ). The IR spectrum showed strong hydroxyl $\left(3461 \mathrm{~cm}^{-1}\right), \gamma$-lactone $\left(1760 \mathrm{~cm}^{-1}\right)$, acetate $\left(1740,1249,1230 \mathrm{~cm}^{-1}\right)$, and olefinic $(1660,962$, $835 \mathrm{~cm}^{-1}$ ) bands. The ${ }^{1} \mathrm{H}-{ }^{1} \mathrm{H}$ COSY spectrum allowed identification of two spin systems in the structure $[\mathrm{A} ; \mathbf{\square}=\mathrm{CH}-$ $\mathrm{CH}(\mathrm{O})-\mathrm{CH}\left(\mathrm{CH}(\mathbf{\square})-\mathrm{CH}_{3}\right)-\mathrm{CH}_{2}-\mathrm{CH}_{2}-\mathbf{\square}, \quad \mathrm{B} ; \quad \mathbf{\square}=\mathrm{CH}-\mathrm{CH}_{2}-$ $\mathrm{CH}(\mathrm{OH})-\mathbf{-}]$, from which a complete molecule could be built by long-range correlation in ${ }^{1} \mathrm{H}-{ }^{1} \mathrm{H}$ COSY spectrum and $\mathrm{HMBC}$ experiments (Fig. 3). The two olefinic protons resonating at $\delta_{\mathrm{H}} 5.13(1 \mathrm{H}, \mathrm{t}, J=7.8 \mathrm{~Hz})$ and $5.58(1 \mathrm{H}$, brd, $J=11.0 \mathrm{~Hz}$ ) exhibited allylic correlations with a vinyl methyl at $\delta_{\mathrm{H}} 1.76\left(3 \mathrm{H}\right.$, brs) and two hydroxymethyl protons at $\delta_{\mathrm{H}}$ 4.05 and $4.11(1 \mathrm{H}$ each, $\mathrm{d}, J=13.1 \mathrm{~Hz})$, respectively, in the ${ }^{1} \mathrm{H}-{ }^{1} \mathrm{H}$ COSY spectrum, which in turn correlated with $\mathrm{C}-1$, C-9 and C-10 and C-3, C-4 and C-5, respectively, implying that partial structures $\mathrm{A}$ and $\mathrm{B}$ could only be linked as a germacranolide skeleton with a hydroxymethyl group bound to C-4. Other key HMBC correlations for H-5 to C-3, C-7, and
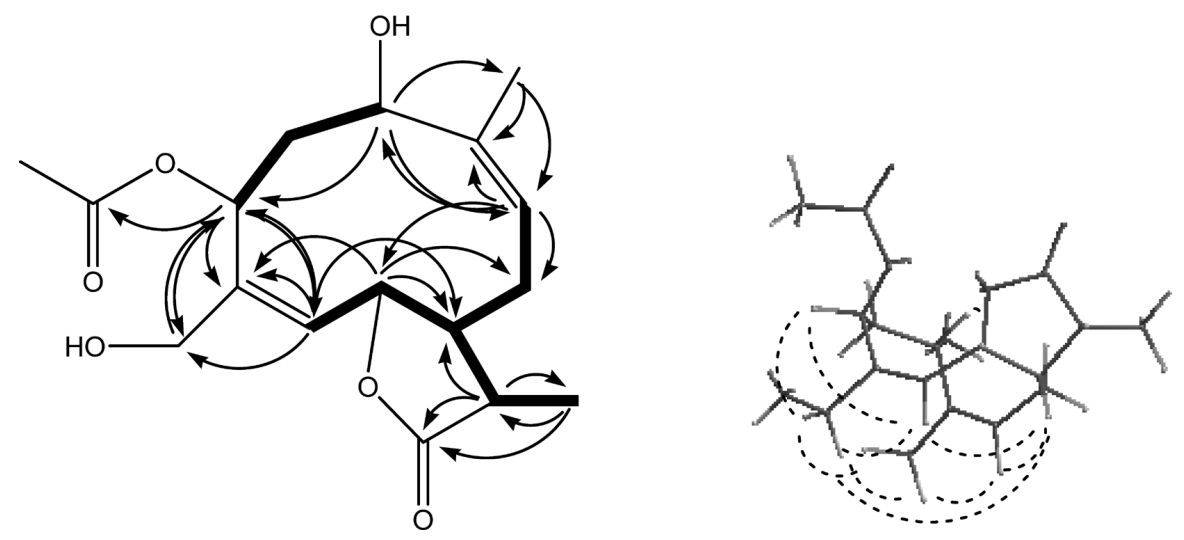

Fig. 2. Selected HMBC (Arrows) and ${ }^{1} \mathrm{H}-{ }^{1} \mathrm{H}$ COSY (Bold Lines) Correlations and NOE (Dot Lines) Correlations for Zawadskinolide A (1) 

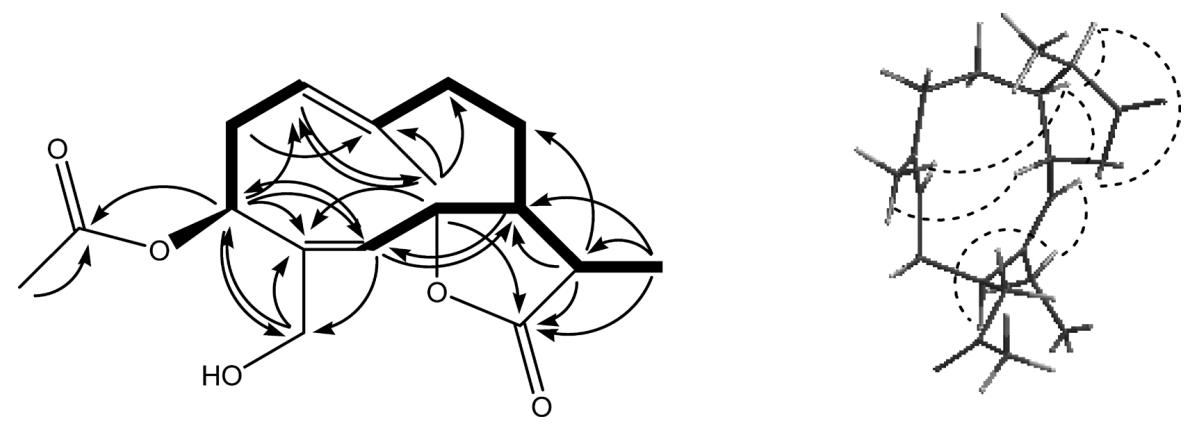

Fig. 3. Selected HMBC (Arrows) and ${ }^{1} \mathrm{H}-{ }^{1} \mathrm{H}$ COSY (Bold Lines) Correlations and NOE (Dot Lines) Correlations for Zawadskinolide B (2)

C-15, H-1 to C-2, C-9, and C-14, and H-6 to C-4, C-7, C-8, and $\mathrm{C}-12$ supported the location of a hydroxyl group at $\mathrm{C}-3$, a hydroxymethyl group at $\mathrm{C}-4$, and the $\gamma$-lactone moiety at C-6 and C-7. An acetoxyl group was attached at C-3 according to the HMBC correlation of $\mathrm{H}-3$ with an acetoxyl $\mathrm{CO}$. The above data strongly suggested that compound $\mathbf{2}$ was a 6,12-germacranolide with a hydroxyl group located at C-15 and an acetoxyl group located at C-3. The coupling constants across the protons at positions $\mathrm{H}-5-\mathrm{H}-7 \quad\left(J_{5,6}=11.0 \mathrm{~Hz}\right.$ and $J_{6,7}$ was very small and not measurable) were equivalent to the literature values for heliangolides such as provincialin, heliangolidin, and ajanolide $\mathrm{A}^{21-23)}$ Further relative stereochemistry of $\mathbf{2}$ was confirmed by NOESY experiment. The NOE correlations (Fig. 3) between H-5 and H-15, H-11 and H-7, between H-3 and H-15, and between $\mathrm{H}-7$ and $\mathrm{H}-1$ and $\mathrm{H}-11$ showed that all these hydrogens lie in the same lower face of the medium ring surface and indicated a $3 \beta$-orientation for the 3-OAc group. The $Z$-configuration of the $\Delta^{4}$-double bond and the $E$-configuration of the $\Delta^{1(10)}$-double bond were confirmed by NOE correlations between H-5 and H-15 and between H-6 and H-14, respectively. Therefore, compound 2 was identified as $3 \beta$-acetoxy-15-hydroxy-germacra-1(10)E,4Z-dien$6 \beta, 7 \alpha, 11 \alpha H$-12,6-olide (15-hydroxyajanolide $\mathrm{A})^{23)}$ and named zawadskinolide B.

Compound 3 had the molecular formula $\mathrm{C}_{17} \mathrm{H}_{24} \mathrm{O}_{6}$ by HRchemical ionization (CI)-MS ( $m / z 325.1657$ [M+H] $]^{+}$; Calcd for $\mathrm{C}_{17} \mathrm{H}_{25} \mathrm{O}_{6}$ 325.1653), and IR bands at 3460, 1765, 1742 and $1242 \mathrm{~cm}^{-1}$ pointed to the presence of hydroxyl, $\gamma$-lactone and acetyl ester groups. Its ${ }^{1} \mathrm{H}$ - and ${ }^{13} \mathrm{C}$-NMR spectra (Tables 1 , 3) exhibited common features with those of 2 . Compound 3 was also a heliangolide, as was evident from the chemical shift values and coupling constants for $\mathrm{H}-5\left(\delta_{\mathrm{H}} 5.75, \mathrm{~d}\right.$, $J=11.4 \mathrm{~Hz}), \mathrm{H}-6\left(\delta_{\mathrm{H}} 5.54, \mathrm{~d}, J=11.4 \mathrm{~Hz}\right)$, and H-7 $\left(\delta_{\mathrm{H}} 2.26\right.$, brt, $J=11.2 \mathrm{~Hz}$ ), which matched the reported values for 2 . The significant changes were the disappearance of the vinyl methyl signal at $\delta_{\mathrm{H}} 1.76$ and an olefinic proton triplet at $\delta_{\mathrm{H}} 5.13$, and the appearance of a methyl singlet at $\delta_{\mathrm{H}} 1.46$ and a doublet of doublets at $\delta_{\mathrm{H}} 2.94(J=4.5,10.2 \mathrm{~Hz})$. These changes suggested the formation of a C-1, C-10 epoxide ring in $3^{15,24,25)}$ Their ${ }^{13} \mathrm{C}-\mathrm{NMR}$ values were also comparable except for the high field shifts of C-1 $\left(\delta_{\mathrm{C}} 61.0 ; \delta_{\mathrm{C}} 121.9\right.$ in 2$)$ and $\mathrm{C}-10\left(\delta_{\mathrm{C}} 60.7 ; \delta_{\mathrm{C}}\right.$ 138.6 in 2), which were also indicative of the presence of an epoxide ring in this position. ${ }^{24,25)}$ The stereochemistry of the epoxide ring was deduced to be $1 \beta, 10 \alpha$ on the basis of the low field displacement of the doublet of H- $6\left(\delta_{\mathrm{H}} 5.54 ; \delta_{\mathrm{H}} 5.12\right.$ brd in 2). ${ }^{20,24-26)}$ Thus, compound 3 was identified as $3 \beta$-acetoxy$1 \beta, 10 \alpha$-epoxy-15-hydroxy-germacr- $4 Z$-en- $6 \beta, 7 \alpha, 11 \alpha H$-12,6olide and named zawadskinolide C (15-hydroxyajanolide A epoxide). ${ }^{25)}$

The IR spectrum of 4 suggested the presence of a hydroxyl group $\left(3388 \mathrm{~cm}^{-1}\right), \gamma$-lactone $\left(1749 \mathrm{~cm}^{-1}\right)$ and olefinic $\left(1647 \mathrm{~cm}^{-1}\right)$ bands. The HR-FAB MS showed a cationized molecular ion peak at $m / z 305.1358[\mathrm{M}+\mathrm{Na}]^{+}$and suggested its molecular formula as $\mathrm{C}_{15} \mathrm{H}_{22} \mathrm{O}_{5}$ (Calcd for $\mathrm{C}_{15} \mathrm{H}_{22} \mathrm{O}_{5} \mathrm{Na}$ 305.1365) and five degrees of unsaturation. The ${ }^{1} \mathrm{H}-\mathrm{NMR}$ spectrum exhibited signals due to a secondary methyl at $\delta_{\mathrm{H}}$ $1.14(3 \mathrm{H}, \mathrm{d}, J=7.4 \mathrm{~Hz})$, two vinyl exomethylene protons at $\delta_{\mathrm{H}}$ $5.12,5.32(1 \mathrm{H}$ each, s), two oxygenated methylene protons at $\delta_{\mathrm{H}} 4.14,4.21(1 \mathrm{H}$ each, $\mathrm{d}, J=12.3 \mathrm{~Hz})$, and three oxygenated methine protons at $\delta_{\mathrm{H}} 4.32(1 \mathrm{H}, \mathrm{dd}, J=4.1,11.6 \mathrm{~Hz})$, $4.61\left(1 \mathrm{H}\right.$, brd, $J=6.6 \mathrm{~Hz}$ ) and 5.32 (overlap). The ${ }^{13} \mathrm{C}-\mathrm{NMR}$ and DEPT spectra showed a secondary methyl group at $\delta_{\mathrm{C}}$ 9.8; three methylene carbons at $\delta_{\mathrm{C}} 40.7,26.3$ and 24.4; three oxygenated methine carbons at $\delta_{\mathrm{C}} 74.5,68.2$ and 77.7; an oxygenated methylene carbon at $\delta_{\mathrm{C}} 66.8$; two methine carbons at $\delta_{\mathrm{C}} 37.2$ and 39.3 ; four olefinic carbons at $\delta_{\mathrm{C}} 148.4,116.3$, 144.7 and 126.5; and a lactone carbon at $\delta_{\mathrm{C}} 179.0$. The ${ }^{1} \mathrm{H}-{ }^{1} \mathrm{H}$ COSY spectrum allowed identification of two spin systems in the structure $\left[\mathrm{A} ; \boldsymbol{\square}=\mathrm{CH}-\mathrm{CH}(\mathrm{O})-\mathrm{CH}\left(\mathrm{CH}(\boldsymbol{\square})-\mathrm{CH}_{3}\right)-\mathrm{CH}_{2}-\right.$ $\left.\mathrm{CH}_{2}-\mathbf{\square}, \mathrm{B} ; \mathbf{\square}-\mathrm{CH}(\mathrm{OH})-\mathrm{CH}_{2}-\mathrm{CH}(\mathrm{OH})-\mathbf{-}\right]$, from which a complete molecule could be built by long-range correlation in ${ }^{1} \mathrm{H}-{ }^{1} \mathrm{H}$ COSY spectrum and HMBC experiments (Fig. 4). The signal resonating at $\delta_{\mathrm{H}} 4.61(1 \mathrm{H}, \mathrm{brd}, J=6.6 \mathrm{~Hz})$ exhibited allylic correlation with $\delta_{\mathrm{H}} 5.55$, which in turn correlated with hydroxymethyl protons at $\delta_{\mathrm{H}} 4.14(1 \mathrm{H}, \mathrm{d}, J=12.3 \mathrm{~Hz})$ and $4.21(1 \mathrm{H}, \mathrm{d}, J=12.3 \mathrm{~Hz})$, implying that a hydroxymethyl group was bound to $\mathrm{C}-4$. The signals at $\delta_{\mathrm{H}} 5.12(1 \mathrm{H}, \mathrm{s}), 5.32$ $(1 \mathrm{H}, \mathrm{s})$ in the ${ }^{1} \mathrm{H}-\mathrm{NMR}$ spectrum, which correlated with $\mathrm{C}-1$, $\mathrm{C}-10$, and $\mathrm{C}-9$ in the HMBC spectrum, and the signals at $\delta_{\mathrm{C}} 116.3$ and $\delta 148.4$ in the ${ }^{13} \mathrm{C}-\mathrm{NMR}$ spectrum were characteristic signals of an exocyclic methylene group at $\mathrm{C}-10$. Furthermore, HMBC correlations for H-5 to C-3, C-4, C-15, and $\mathrm{C}-7$ and for $\mathrm{H}-6$ to $\mathrm{C}-4$ and $\mathrm{C}-12$ supported the location of the hydroxymethyl group at $\mathrm{C}-4$ and the $\gamma$-lactone moiety at C-6 and C-7. The five degrees of unsaturation only allowed for the existence of two rings. The above data suggested that 4 was a germacranolide-type sesquiterpene lactone. Some of the signals in the ${ }^{1} \mathrm{H}-\mathrm{NMR}$ spectrum were broadened due to the conformational exchange. Thus, an acetate derivative (4a) was prepared and measured. The signal of H-6 in $\mathbf{4 a}\left(\delta_{\mathrm{H}} 5.36\right.$, $\mathrm{d}, J=8.1 \mathrm{~Hz}$ ), assigned by ${ }^{1} \mathrm{H}-{ }^{1} \mathrm{H}$ COSY, showed coupling only with $\mathrm{H}-5$ at $\delta_{\mathrm{H}} 5.71(\mathrm{~d}, J=8.1 \mathrm{~Hz})$ and no coupling with $\mathrm{H}-7$, which were equivalent to the literature values for 6,7-trans heliangolides. $^{18,22,23)}$ The relative stereochemistry of $\mathbf{4}$ was determined by comparison of the spectral data of $\mathbf{4}$ with those recorded for other known heliangolide-type sesquiterpene lac- 
Table 1. ${ }^{1} \mathrm{H}-\mathrm{NMR}$ Data of $\mathbf{1}-\mathbf{3}$ in $\mathrm{CD}_{3} \mathrm{OD}$

\begin{tabular}{|c|c|c|c|}
\hline \multirow{2}{*}{ No. } & 1 & $2^{a)}$ & 3 \\
\hline & $\delta_{\mathrm{H}}(J, \text { in } \mathrm{Hz})^{b)}$ & $\delta_{\mathrm{H}}(J, \text { in } \mathrm{Hz})^{b)}$ & $\delta_{\mathrm{H}}(J, \text { in } \mathrm{Hz})^{b)}$ \\
\hline 1 & $4.88(\mathrm{dd}, 1.2,11.1)$ & $5.13(\mathrm{t}, 7.8)$ & $2.94(\mathrm{dd}, 4.5,10.2)$ \\
\hline \multirow[t]{2}{*}{2} & $1.91(\mathrm{ddd}, 3.0,4.7,15.0)$ & $2.27(\mathrm{dq}, 6.3,15.8)$ & 1.75 (overlap) \\
\hline & $2.24(\mathrm{ddd}, 1.8,11.4,15.0)$ & $2.73($ brt, 11.0$)$ & $2.60(\mathrm{dt}, 4.8,15.4)$ \\
\hline 3 & $5.47(\mathrm{dd}, 3.3,4.1)$ & $5.31(\mathrm{dd}, 2.4,3.9)$ & $5.25(\mathrm{dd}, 1.7,4.9)$ \\
\hline 5 & $5.35(\mathrm{brd}, 10.3)$ & $5.58(\mathrm{brd}, 11.0)$ & $5.75(\mathrm{~d}, 11.4)$ \\
\hline 6 & $5.64(\mathrm{t}, 10.3)$ & $5.12($ brd, 11.0$)$ & $5.54(\mathrm{~d}, 11.4)$ \\
\hline 7 & 2.15 (overlap) & $2.19($ brt, 11.0$)$ & $2.26(\mathrm{brt}, 11.2)$ \\
\hline \multirow[t]{2}{*}{8} & $2.15(\mathrm{tt}, 4.6,13.8)$ & $1.38(\mathrm{ddd}, 2.6,12.4,12.5)$ & $1.47(\mathrm{ddd}, 3.0,12.0,24.0)$ \\
\hline & 2.57 (brdd, 12.6, 24.4) & $1.66(\mathrm{~m})$ & 1.78 (overlap) \\
\hline \multirow[t]{2}{*}{9} & $5.24(\mathrm{brdd}, 6.5,9.8)$ & $2.06(t, 7.2)$ & $1.07(\mathrm{ddd}, 2.8,13.6,13.6)$ \\
\hline & & $2.32(\mathrm{brd}, 15.8)$ & $2.35(\mathrm{dq}, 13.8)$ \\
\hline 11 & $2.70(\mathrm{dq}, 7.8,7.9)$ & $2.90(\mathrm{dq}, 7.3,8.3)$ & $3.10(\mathrm{dq}, 7.4,8.2)$ \\
\hline 13 & $1.24(\mathrm{~d}, 7.8)$ & $1.17(\mathrm{~d}, 7.4)$ & $1.14(\mathrm{~d}, 7.4)$ \\
\hline 14 & $1.65(\mathrm{~s})$ & $1.76(\mathrm{brs})$ & $1.46(\mathrm{~s})$ \\
\hline \multirow[t]{2}{*}{15} & $3.98($ brd, 0.6$)$ & $4.05(\mathrm{~d}, 13.1)$ & $4.11(\mathrm{~d}, 14.0)$ \\
\hline & & $4.11(\mathrm{~d}, 13.1)$ & $4.16(\mathrm{~d}, 14.0)$ \\
\hline OAc & $2.10(\mathrm{~s})$ & $2.03(\mathrm{~s})$ & $2.06(\mathrm{~s})$ \\
\hline
\end{tabular}

a) Data recorded in $\mathrm{CDCl}_{3}$. b) Data recorded at $400 \mathrm{MHz}$.

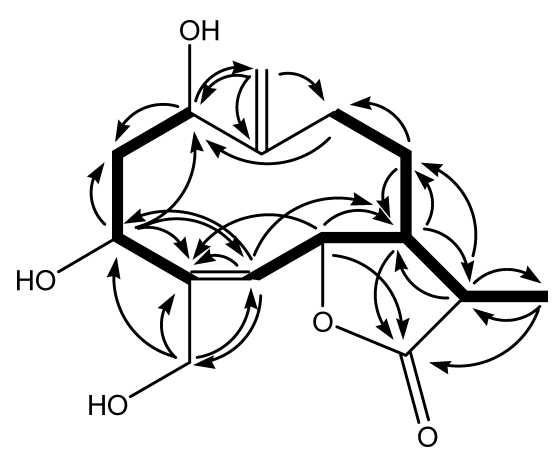

Fig. 4. Selected HMBC (Arrows) and ${ }^{1} \mathrm{H}-{ }^{1} \mathrm{H}$ COSY (Bold Lines) Correlations for Zawadskinolide D (4)

tones, ${ }^{18)}$ as well as from the NOESY spectrum. The coupling constants of H-1 $(J=4.1,11.6 \mathrm{~Hz})$ and $\mathrm{H}-3(J=6.6 \mathrm{~Hz})$ and the NOE correlations between $\mathrm{H}-3$ and $\mathrm{H}-7$ and $\mathrm{H}-1$ and between $\mathrm{H}-7$ and $\mathrm{H}-11$ showed that all these hydrogens lie in the same lower face of the medium ring surface and indicated $1 \beta, 3 \beta$ orientations for the 1,3-OH groups. ${ }^{18)}$ An NOE correlation was also observed between $\mathrm{H}-1$ and one $\left(\delta_{\mathrm{H}}\right.$ 5.32) of the exomethylene protons. The $Z$-configuration of the $\Delta^{4}$-double bond was confirmed by the NOE correlation between $\mathrm{H}-5$ and $\mathrm{H}-15$. The chemical shifts and the values of the coupling constants of $\mathrm{H}-13$ at $\delta_{\mathrm{H}} 1.14(\mathrm{~d}, J=7.4 \mathrm{~Hz})$ and $\mathrm{H}-11$ at $\delta_{\mathrm{H}} 2.75(\mathrm{dq}, J=7.9$, $7.8 \mathrm{~Hz}$ ), as well as the chemical shift of $\mathrm{C}-13$ at $\delta_{\mathrm{C}} 9.8$, suggested that both $\mathrm{H}-7$ and $\mathrm{H}-11$ were in the cis-configuration relative to each other. ${ }^{18,20,27)}$ All these results established that 4 was $1 \beta, 3 \beta, 15$-trihydroxy-germacra- $4 Z, 10(14)$-dien- $6 \beta, 7 \alpha, 11 \alpha H$ 12,6-olide and named zawadskinolide D.

Compounds 5 and $\mathbf{6}$ each had a molecular formula of $\mathrm{C}_{17} \mathrm{H}_{24} \mathrm{O}_{6}$ based on their HR-CI-MS data at $\mathrm{m} / \mathrm{z} 325.1651$ $[\mathrm{M}+\mathrm{H}]^{+}$(Calcd for $\mathrm{C}_{17} \mathrm{H}_{25} \mathrm{O}_{6} 325.1653$ ) for $\mathbf{5}$ and $\mathrm{m} / \mathrm{z} 323.1493$ $[\mathrm{M}-\mathrm{H}]^{+}$(Calcd for $\mathrm{C}_{17} \mathrm{H}_{23} \mathrm{O}_{6}$ 323.1495) for 6. This was 42 mass units higher than the $\mathrm{M}^{+}$signal for 4 , indicating the presence of an additional acetyl group in 5 and $\mathbf{6}$. The ${ }^{1} \mathrm{H}$ and ${ }^{13} \mathrm{C}$-NMR spectra of 5 and $\mathbf{6}$ (Tables 2, 3) were similar to those of compound $\mathbf{4}$, which indicated that $\mathbf{5}$ and $\mathbf{6}$ were the same germacranolide derivatives. Compounds $\mathbf{5}$ and $\mathbf{6}$ were esterified at C-15 and C-3, respectively, as evidenced by the long-range correlations between $\mathrm{H}-15$ and acetoxyl $\mathrm{CO}$ and between $\mathrm{H}-3$ and acetoxyl $\mathrm{CO}$, respectively, observed in the HMBC spectrum. Correlations observed in the NOESY spectrum confirmed the same configuration of the heliangolide skeleton as in compound $\mathbf{4}$. Treatment of $\mathbf{5}$ and $\mathbf{6}$ with acetic anhydride in pyridine yielded the same triacetylated product, which proved to be identical with $\mathbf{4 a}$ obtained from $\mathbf{4}$ by the same treatment. All these results established that $\mathbf{5}$ and 6 were 15 -acetoxy-1 $\beta, 3 \beta$-dihydroxy-germacra- $4 Z, 10(14)$-dien$6 \beta, 7 \alpha, 11 \alpha H$-12,6-olide (zawadskinolide E) and $3 \beta$-acetoxy$1 \beta, 15$-dihydroxy-germacra-4Z,10(14)-dien- $6 \beta, 7 \alpha, 11 \alpha H-12,6$ olide (zawadskinolide F), respectively.

The spectroscopic features of compound 7, a very unstable compound, resembled those of oplodiol $1-O-\beta$-Dglucopyranoside (8) ${ }^{28)}$ Comparison of the NMR spectra of 7 with those of $\mathbf{8}$, showed that most of the $\mathrm{C}$-atom resonances (Table 3) were almost superimposable. Moreover, the signals of two geminal protons at $\delta_{\mathrm{H}} 3.39(1 \mathrm{H}, \mathrm{dd}, J=7.6,10.8 \mathrm{~Hz}$, $\mathrm{H}-12 \mathrm{a})$ and $3.56(1 \mathrm{H}, \mathrm{dd}, J=6.7,10.8 \mathrm{~Hz}, \mathrm{H}-12 \mathrm{~b})$, instead of the methyl protons in the isopropyl group of $\mathbf{8}$, indicated one methyl carbon was oxygenated in 7 . The eudesmane skeleton of 7 was unambiguously determined using the combinations of ${ }^{1} \mathrm{H}-{ }^{1} \mathrm{H}$ COSY, heteronuclear multiple quantum coherence (HMQC) and HMBC spectroscopic data. Thus, compound 7 was established as $1 \beta, 4 \beta, 12$-trihydroxy-eudesm-7-ene 1- $O$ - $\beta$-Dglucopyranoside and named chrysantiloboside.

The other compounds were identified as apigenin (9), ${ }^{29)}$ (-)-eriodictyol (10), ${ }^{30)} p$-hydroxybenzoic acid (11), ${ }^{31)}$ nepetin $(12),{ }^{32)}$ oplodiol $1-O-\beta$-D-glucopyranoside $(\mathbf{8}),{ }^{28)}$ luteolin 7- $O$-glucoside (13), ${ }^{33)}$ linarin (14), ${ }^{34)}$ syringaresinol $\beta$-Dglucoside $(\mathbf{1 5}),{ }^{29)}$ uridine $(\mathbf{1 6}),{ }^{35)}$ dihydrodehydrodiconiferyl alcohol 9- $O-\beta$-D-glucopyranoside $(\mathbf{1 7}),{ }^{36)}$ benzyl $6-O-\beta$-Dapiofuranosyl $(1 \rightarrow 6)$ - $\beta$-D-glucopyranoside (icariside $\left.\left.\mathrm{F}_{2}\right)(\mathbf{1 8}),{ }^{37}\right)$ $(Z)$-3-hexenyl- $O$-vicianoside (19), ${ }^{38)}$ and phenethyl- $O$-vicianoside $(\mathbf{2 0})^{38)}$ on the basis of spectral data and chemical evidence, which were in good agreement with those reported 
Table 2. ${ }^{1} \mathrm{H}-\mathrm{NMR}$ Data of $\mathbf{4}-\mathbf{6}$ in $\mathrm{CDCl}_{3}$

\begin{tabular}{|c|c|c|c|}
\hline \multirow{2}{*}{ No. } & 4 & 5 & $6^{a)}$ \\
\hline & $\delta_{\mathrm{H}}(J, \text { in } \mathrm{Hz})^{b)}$ & $\delta_{\mathrm{H}}(J, \text { in } \mathrm{Hz})^{c)}$ & $\left.\delta_{\mathrm{H}}(J, \text { in } \mathrm{Hz})^{c}\right)$ \\
\hline 1 & $4.32(\mathrm{dd}, 4.1,11.6)$ & $4.21(\mathrm{dt}, 3.5,11.1)$ & $4.27(\mathrm{dd}, 3.0,11.1)$ \\
\hline \multirow[t]{2}{*}{2} & 1.95 (ddd, 4.1, 8.0, 15.1) & 1.94 (ddd, 3.9, 7.4, 14.9) & $2.37(\mathrm{ddd}, 2.8,11.2,15.3)$ \\
\hline & $2.11(\mathrm{ddd}, 1.5,11.6,15.1)$ & 2.10 (overlap) & $2.46(\mathrm{ddd}, 3.3,5.7,15.3)$ \\
\hline 3 & $4.61(\mathrm{brd}, 6.6)$ & 4.50 (overlap) & 5.45 (brdd, 2.7, 5.6) \\
\hline 5 & 5.55 (brd, 3.6) & 5.57 (brd, 5.6) & 5.74 (brd, 9.8) \\
\hline 6 & 5.32 (overlap) & $5.42(\mathrm{brd}, 5.6)$ & $5.60($ brd, 9.8$)$ \\
\hline 7 & $2.62(\mathrm{ddd}, 2.0,7.8,11.0)$ & $2.56(\mathrm{brt}, 10.4)$ & $2.52(\mathrm{brt}, 11.0)$ \\
\hline \multirow[t]{2}{*}{8} & $1.46(\mathrm{tt}, 4.3,13.5,13.5)$ & $1.46(\mathrm{tt}, 4.6,13.8)$ & $1.42(\mathrm{ddd}, 3.8,10.1,13.8)$ \\
\hline & $1.81(\mathrm{brt}, 13.5)$ & $1.80(\mathrm{tdd}, 3.4,9.7,13.8)$ & 1.93 (brt, 13.8) \\
\hline \multirow[t]{2}{*}{9} & $2.27(\mathrm{dt}, 4.8,15.7)$ & $2.20(\mathrm{dt}, 4.9,15.4)$ & 2.21 (ddd, 4.0, 10.4, 14.3) \\
\hline & 2.37 (ddd, 4.1, 11.8, 15.7) & $2.40(\mathrm{ddd}, 3.8,10.8,15.4)$ & $2.60(\mathrm{dq}, 4.3,14.3)$ \\
\hline 11 & $2.75(\mathrm{dq}, 7.9,7.8)$ & $2.74(\mathrm{dq}, 7.4,7.8)$ & $3.02(\mathrm{dq}, 7.4,8.0)$ \\
\hline 13 & $1.14(\mathrm{~d}, 7.4)$ & $1.12(\mathrm{~d}, 7.4)$ & $1.15(\mathrm{~d}, 7.4)$ \\
\hline \multirow[t]{2}{*}{14} & $5.12(\mathrm{~s})$ & $5.08(\mathrm{~s})$ & 5.34 (brs) \\
\hline & $5.32(\mathrm{~s})$ & $5.27(\mathrm{~s})$ & 5.36 (brs) \\
\hline \multirow[t]{2}{*}{15} & $4.14(\mathrm{~d}, 12.3)$ & $4.50(\mathrm{~d}, 13.1)$ & $4.04(\mathrm{~d}, 14.5)$ \\
\hline & $4.21(\mathrm{~d}, 12.3)$ & $4.60(\mathrm{~d}, 13.1)$ & $4.11(\mathrm{~d}, 14.5)$ \\
\hline OAc & & $2.05(\mathrm{~s})$ & $1.99(\mathrm{~s})$ \\
\hline
\end{tabular}

a) Data recorded in $\mathrm{CD}_{3} \mathrm{OD}$. b) Data recorded at $500 \mathrm{MHz}$. c) Data recorded at $400 \mathrm{MHz}$.

Table 3. ${ }^{13} \mathrm{C}-\mathrm{NMR}$ Data of $\mathbf{1}-\mathbf{8}$ and $\mathbf{4 a}$

\begin{tabular}{|c|c|c|c|c|c|c|c|c|c|c|}
\hline \multirow{2}{*}{ No. } & $\mathbf{1}^{a)}$ & $\mathbf{2}^{b)}$ & $\mathbf{3}^{a)}$ & $4^{b)}$ & $\mathbf{5}^{b)}$ & $6^{a)}$ & $4 a^{b)}$ & \multirow{2}{*}{ No. } & $7^{a)}$ & \multirow{2}{*}{$\frac{\mathbf{8}^{a)}}{\delta_{\mathrm{C}}{ }^{c)}}$} \\
\hline & $\delta_{\mathrm{C}}^{c)}$ & $\delta_{\mathrm{C}}^{c)}$ & $\delta_{\mathrm{C}}^{c)}$ & $\delta_{\mathrm{C}}^{d)}$ & $\delta_{\mathrm{C}}^{c)}$ & $\delta_{\mathrm{C}}^{c}{ }^{c}$ & $\delta_{\mathrm{C}}^{d)}$ & & $\delta_{\mathrm{C}}^{c)}$ & \\
\hline 1 & 64.7 & 121.9 & 61.0 & 74.5 & 73.7 & 86.3 & 73.2 & & 86.8 & 86.8 \\
\hline 2 & 34.0 & 30.4 & 32.8 & 40.7 & 40.1 & 33.2 & 34.7 & & 23.8 & 23.8 \\
\hline 3 & 72.4 & 74.4 & 71.5 & 68.2 & 67.6 & 72.0 & 69.1 & & 40.2 & 40.2 \\
\hline 4 & 140.9 & 139.4 & 142.6 & 144.7 & 140.6 & 143.1 & 136.5 & & 71.4 & 71.4 \\
\hline 5 & 126.8 & 126.4 & 124.5 & 126.5 & 128.0 & 125.7 & 129.9 & & 48.4 & 48.4 \\
\hline 6 & 81.8 & 81.2 & 80.9 & 77.7 & 77.9 & 80.3 & 77.7 & & 24.5 & 24.1 \\
\hline 7 & 43.4 & 44.7 & 45.0 & 39.3 & 40.2 & 44.5 & 41.6 & & 139.1 & 142.8 \\
\hline 8 & 26.7 & 24.2 & 24.6 & 26.3 & 26.5 & 29.6 & 27.5 & & 120.7 & 117.9 \\
\hline 9 & 126.1 & 40.4 & 40.9 & 24.4 & 26.0 & 33.6 & 29.4 & & 41.9 & 41.9 \\
\hline 10 & 139.9 & 138.6 & 60.7 & 148.4 & 148.5 & 145.9 & 144.0 & & 38.3 & 38.3 \\
\hline 11 & 40.4 & 36.0 & 36.5 & 37.2 & 37.3 & 38.1 & 37.0 & & 44.5 & 36.4 \\
\hline 12 & 182.0 & 179.6 & 180.9 & 179.0 & 179.2 & 181.9 & 178.8 & & 67.1 & 22.3 \\
\hline 13 & 11.3 & 10.8 & 9.7 & 9.8 & 9.8 & 10.5 & 10.0 & & 16.9 & 21.7 \\
\hline 14 & 17.3 & 17.0 & 16.1 & 116.3 & 115.7 & 118.8 & 118.3 & & 13.1 & 13.0 \\
\hline 15 & 65.5 & 66.1 & 65.0 & 66.8 & 65.9 & 65.1 & 66.0 & & 29.9 & 29.9 \\
\hline \multirow[t]{6}{*}{ OAc } & 21.1 & 21.2 & 20.3 & & 21.0 & 21.0 & 20.8 & $1^{\prime}$ & 101.8 & 101.9 \\
\hline & 171.1 & 170.4 & 170.4 & & 170.9 & 171.7 & 169.9 & $2^{\prime}$ & 75.1 & 75.1 \\
\hline & & & & & & & 20.9 & $3^{\prime}$ & 78.3 & 78.3 \\
\hline & & & & & & & 170.1 & $4^{\prime}$ & 71.9 & 71.9 \\
\hline & & & & & & & 21.1 & $5^{\prime}$ & 77.8 & 77.8 \\
\hline & & & & & & & 170.3 & $6^{\prime}$ & 63.0 & 63.0 \\
\hline
\end{tabular}

a) Data recorded in $\mathrm{CD}_{3} \mathrm{OD}$. b) Data recorded in $\mathrm{CDCl}_{3} . c$ ) Data recorded at $100 \mathrm{MHz} . d$ ) Data recorded at $125 \mathrm{MHz}$.

in the literature. Of these, compounds $\mathbf{8}, \mathbf{1 0}-\mathbf{1 2}$, and $\mathbf{1 5}-\mathbf{2 0}$ were isolated from this plant for the first time.

In view of the traditional medicinal uses of D. zawadskii var. latilobum ${ }^{2)}$ and the previous report on its anti-inflammatory activity, ${ }^{14)}$ the isolated compounds $(\mathbf{1}-\mathbf{6}, \mathbf{8}-\mathbf{1 8}, \mathbf{2 0})$ were evaluated for their inhibitory effects on NO release in LPSstimulated RAW 264.7 macrophage cells. As shown in Table 4, flavonoids such as apigenin (9), eriodictyol (10) and nepetin (12), as well as the sesquiterpene lactone, zawadskinolide $\mathrm{F}$ (6), showed moderate inhibitory activity against NO produc- tion with $\mathrm{IC}_{50}$ values of $66.15,132.55,35.44$, and $91.32 \mu \mathrm{M}$, respectively. The cytotoxic effects of these compounds were measured using the (4,5-dimethylthiazol-2-yl)-2,5-diphenyl tetrazolium bromide (MTT) assay. Only apigenin (9) and nepetin (12) showed cytotoxicity with $\mathrm{IC}_{50}$ values of 112.24 and $142.07 \mu \mathrm{M}$, respectively; the other compounds did not show any significant cytotoxicity. Therefore, the anti-NO production by both compounds was not the result of cell death. Although it was reported that the $\mathrm{MeOH}$ extract of $D$. zawadskii var. latilobum inhibited NO production in LPS-stimulated 
Table 4. Effects of Fractions and Compounds on Cell Viability and Nitrite Production in RAW 264.7 Macrophages ${ }^{a}$

\begin{tabular}{|c|c|c|}
\hline \multirow{2}{*}{ Compound } & \multicolumn{2}{|c|}{$\mathrm{IC}_{50}(\mu \mathrm{M})^{b)}$} \\
\hline & Cell viability & Nitrite inhibition \\
\hline $\mathrm{MeOH}$ extract ${ }^{c)}$ & $35.73 \pm 2.48$ & - \\
\hline Hexane fraction ${ }^{c)}$ & $75.50 \pm 5.99$ & - \\
\hline $\mathrm{CH}_{2} \mathrm{Cl}_{2}$ fraction $^{c)}$ & $>200$ & $227.35 \pm 2.94$ \\
\hline EtOAc fraction ${ }^{c)}$ & $>200$ & $44.51 \pm 3.29$ \\
\hline $\mathrm{BuOH}_{\text {fraction }}{ }^{c)}$ & $>200$ & - \\
\hline Zawadskinolide F (6) & - & $91.32 \pm 3.84$ \\
\hline Apigenin (9) & $112.24 \pm 13.09$ & $66.15 \pm 13.65$ \\
\hline$(-)$-Eriodictyol (10) & - & $132.55 \pm 4.00$ \\
\hline Nepetin (12) & $142.07 \pm 8.65$ & $35.44 \pm 4.96$ \\
\hline AMT (Positive control) & & 0.02 \\
\hline
\end{tabular}

a) Zawadskinolides A (1), B (2), C (3), D (4), and E (5), oplodiol 1- $O$ - $\beta$-D-glucopyranoside (8), 4-hydroxybenzoic acid (11), luteolin 7- $O$-glucoside (13), linarin (14), syringaresinol $\beta$-D-glucoside (15), uridine (16), dihydrodehydrodiconiferyl alcohol 9- $O$ - $\beta$-D-glucopyranoside (17), icariside $\mathrm{F}_{2}(\mathbf{1 8})$, and phenethyl- $O$-vicianoside (20) showed no significant effect on the cell viability and nitrite production in RAW 264.7 cells. b) $50 \%$ inhibition concentrations were expressed as the mean \pm S.D. of triplicates. $c$ ) $\mathrm{IC}_{50}$ values are $\mu \mathrm{g} / \mathrm{mL}$.

RAW 264.7 macrophage cells, the anti-NO component was not identified previously. In this study, we demonstrated that the $\mathrm{MeOH}$ extract did not show inhibitory activity against $\mathrm{NO}$ production, but $\mathrm{CH}_{2} \mathrm{Cl}_{2}$ and EtOAc fractions showed inhibitory activity with $\mathrm{IC}_{50}$ values of 227.35 and $44.51 \mu \mathrm{g} / \mathrm{mL}$, respectively (Table 4). Our results suggest that flavonoids and a sesquiterpene lactone in D. zawadskii var. latilobum partially contribute to its anti-inflammatory effects.

In conclusion, seven new compounds $(\mathbf{1}-\mathbf{7})$ and 13 known compounds $(\mathbf{8}-\mathbf{2 0})$ were isolated from the aerial parts of D. zawadskii var. latilobum, and their structures were determined by spectroscopic analysis. The set of germacrane-based metabolites, all of which are novel compounds that have an oxidized C-15 and are either hydroxymethyl or acetyl derivatives, have been named zawadskinolides $\mathrm{A}-\mathrm{F}$ and are divided into a rare cis-cis germacranolide and five heliangolide-type sesquiterpene lactones. Sesquiterpenes are common constituents of the genus Dendranthema, but this species provides the first example of germacranolide and eudesmane-type sesquiterpenes. Flavonoids such as apigenin (9), eriodictyol (10) and nepetin (12), as well as a sesquiterpene lactone, zawadskinolide $\mathrm{F}(\mathbf{6})$, showed moderate inhibitory activity against NO production in LPS-stimulated RAW 264.7 macrophage cells.

\section{Experimental}

General Optical rotations were determined on a JASCO P-1020 polarimeter. UV spectra were obtained with a Hitachi JP/U3010 spectrometer and IR spectra were obtained on a JASCO FT/IR-5300 spectrometer. The EI, FAB and CI mass spectra were obtained on a JEOL JMS-700 spectrometer. The NMR spectra were measured on a Bruker Avance-400 $(400 \mathrm{MHz})$ or a Bruker Avance-500 (500 MHz), and the chemical shifts were referenced to tetramethylsilane (TMS). Column chromatography (CC) was run on silica gel $60(70-230$ mesh or 230-400 mesh, Merck), LiChroprep $\mathrm{RP}_{18}(40-63 \mu \mathrm{m}$, Merck) and Sephadex LH-20 (Amersham Biosciences AB). TLC was performed on silica gel $60 \mathrm{~F}_{254}$ plates (Merck) and RP- $18_{254 \mathrm{~S}}$ plates (Merck). TLC plates were visualized using UV light, staining with $\mathrm{I}_{2}$ vapor or spraying with $20 \% \mathrm{H}_{2} \mathrm{SO}_{4}$ followed by heating. Unless otherwise indicated, all the chemicals for bioassays were purchased from Sigma-Aldrich Co. (St. Louis, MO, U.S.A.).
Plant Material The aerial parts of D. zawadskii var. latilobum were collected at Yungcheon, Kyungbok Province, Korea, in September 2005. The botanical identification was made by Prof. Y.-B. Suh. A voucher specimen (SHJ2008-1) was deposited in the Natural Products Research Institute, College of Pharmacy, Seoul National University.

Extraction and Isolation The crushed aerial parts $(1.1 \mathrm{~kg})$ were extracted five times with $\mathrm{MeOH}$ under reflux $\left(70-80^{\circ} \mathrm{C}\right)$ to give an extract $(130 \mathrm{~g})$. The $\mathrm{MeOH}$ extract was suspended in water and successively partitioned with hexane, $\mathrm{CH}_{2} \mathrm{Cl}_{2}$, EtOAc and $n-\mathrm{BuOH}$ to yield $15.8,29.5,11.2,13.5$ and $55.2 \mathrm{~g}$ fractions, respectively. A portion of the $\mathrm{CH}_{2} \mathrm{Cl}_{2}$ fraction (29 g) was subjected to silica gel $\mathrm{CC}$ and eluted with $\mathrm{CH}_{2} \mathrm{Cl}_{2}-$ $\mathrm{MeOH}$ mixtures with increasing amounts of $\mathrm{MeOH}(0,30$, $50,70,100 \%, 300 \mathrm{~mL}$ each) to furnish fourteen fractions (M-01-M-14). Fraction M-03 was submitted to silica gel CC using hexane-EtOAc $(2: 1,1: 1,1: 5,1: 10,150 \mathrm{~mL}$ each) to yield 20 fractions. Fraction M-03-13 (170 mg) was successively purified by $\mathrm{CC}$ on $\mathrm{RP}-18$ with $\mathrm{MeOH}-\mathrm{H}_{2} \mathrm{O}(6: 4,300 \mathrm{~mL})$ and silica gel with $\mathrm{CH}_{2} \mathrm{Cl}_{2}-\mathrm{MeOH}-\mathrm{H}_{2} \mathrm{O}(14: 1: 1,500 \mathrm{~mL})$, respectively, to afford compounds $\mathbf{1}(13 \mathrm{mg})$ and $\mathbf{5}(10 \mathrm{mg})$. Fraction M-08 (3 g) was successively purified by CC on silica gel with hexane-EtOAc $(3: 1,1: 1,1: 10,200 \mathrm{~mL}$ each) and silica gel with $\mathrm{CH}_{2} \mathrm{Cl}_{2}-\mathrm{MeOH}-\mathrm{H}_{2} \mathrm{O}(14: 1: 1,500 \mathrm{~mL})$, respectively, to yield 10 fractions. Further CC of fraction $5(320 \mathrm{mg})$ on RP-18 with $\mathrm{MeOH}-\mathrm{H}_{2} \mathrm{O}(1: 1,200 \mathrm{~mL})$ yielded 2 (10 mg). Fraction M-10 (3g) was successively purified by $\mathrm{CC}$ on silica gel with $\mathrm{CH}_{2} \mathrm{Cl}_{2}-\mathrm{MeOH}-\mathrm{H}_{2} \mathrm{O}(14: 1: 1,500 \mathrm{~mL})$ and RP-18 with $\mathrm{MeOH}-\mathrm{H}_{2} \mathrm{O}(6: 4,300 \mathrm{~mL})$, respectively, to afford compounds 3 (11 mg) and 6 (12 mg).

The EtOAc fraction $(11.2 \mathrm{~g})$ was purified by silica gel CC and eluted with hexane-EtOAc mixtures of increasing polarity to yield 30 fractions (E-01-E-30). Fraction E-04 was crystallized from $\mathrm{MeOH}$ to yield 9 ( $2 \mathrm{mg}$ ). Fraction E-08 was purified by silica gel $\mathrm{CC}$ with $\mathrm{CH}_{2} \mathrm{Cl}_{2}-\mathrm{MeOH}-\mathrm{H}_{2} \mathrm{O}$ (14:1:1, $1 \mathrm{~L})$ to yield 25 fractions. Fraction E-08-03 was crystallized from $\mathrm{MeOH}$ to yield $\mathbf{1 0}(5 \mathrm{mg})$. Fraction E-08-05 was chromatographed over silica gel with $\mathrm{CH}_{2} \mathrm{Cl}_{2}-\mathrm{MeOH}-\mathrm{H}_{2} \mathrm{O}$ (14:2:1, $200 \mathrm{~mL}$ ) to yield 11 (4 mg). Fraction E-08-15 was crystallized from $\mathrm{MeOH}$ to yield 12 (66 mg). Fraction E-08-16 was successively purified by $\mathrm{CC}$ on silica gel with $\mathrm{CH}_{2} \mathrm{Cl}_{2}-\mathrm{MeOH}-\mathrm{H}_{2} \mathrm{O}$ $(14: 1: 1,300 \mathrm{~mL})$ and Sephadex LH-20 $(\mathrm{MeOH})$, respectively, 
to afford compound 4 (10 mg). E-08-18 was successively purified by $\mathrm{CC}$ on silica gel with hexane-EtOAc $(5: 8,250 \mathrm{~mL})$ and $\mathrm{RP}-18$ with $\mathrm{MeOH}-\mathrm{H}_{2} \mathrm{O}(6: 4,300 \mathrm{~mL})$, respectively, to afford compound 8 (5 mg). Fraction E-08-21 was purified by silica gel $\mathrm{CC}$ with $\mathrm{CH}_{2} \mathrm{Cl}_{2}-\mathrm{MeOH}-\mathrm{H}_{2} \mathrm{O}(14: 1: 1,200 \mathrm{~mL})$ to yield eight fractions; fraction 5 was crystallized from $\mathrm{MeOH}$ to yield 13 (3 mg). Fraction E-08-25 was crystallized from EtOAc-MeOH to yield $14(170 \mathrm{mg})$.

The $n-\mathrm{BuOH}$ fraction $(13.5 \mathrm{~g})$ was subjected to silica gel CC with $\mathrm{CH}_{2} \mathrm{Cl}_{2}-\mathrm{MeOH}-\mathrm{H}_{2} \mathrm{O}(15: 2: 1$ and then $6: 4: 1,700 \mathrm{~mL}$ each) to yield 15 fractions (B-01-B-15). Fraction B-04 was successively purified by $\mathrm{CC}$ on silica gel with $\mathrm{CH}_{2} \mathrm{Cl}_{2}$ $\mathrm{MeOH}-\mathrm{H}_{2} \mathrm{O}(14: 1: 1,400 \mathrm{~mL})$ and Sephadex LH-20 (MeOH), respectively, to afford compound 15 (4 mg). Fraction B-12 was chromatographed over silica gel using $\mathrm{MeOH}-\mathrm{EtOAc}$ saturated with $\mathrm{H}_{2} \mathrm{O}(1: 100,3: 100,5: 100$, and then $10: 100$, $250 \mathrm{~mL}$ each) to yield 18 fractions. Fraction B-12-04 was applied to an RP-18 column using $\mathrm{MeOH}-\mathrm{H}_{2} \mathrm{O}(1: 1,200 \mathrm{~mL})$ to yield $16(2 \mathrm{mg})$. Fraction B-12-09 was successively purified by $\mathrm{CC}$ on silica gel with $\mathrm{CH}_{2} \mathrm{Cl}_{2}-\mathrm{MeOH}-\mathrm{H}_{2} \mathrm{O}(14: 1: 1,300 \mathrm{~mL})$ and $\mathrm{RP}-18$ with $\mathrm{MeOH}-\mathrm{H}_{2} \mathrm{O}(6: 4,200 \mathrm{~mL})$, respectively, to afford compounds 17 (3 mg), 18 (13 mg), and 7 (8 mg). Fraction B-12-17 was successively purified by $\mathrm{CC}$ on RP-18 using $\mathrm{MeOH}-\mathrm{H}_{2} \mathrm{O}(3: 7,250 \mathrm{~mL})$, silica gel with $\mathrm{CH}_{2} \mathrm{Cl}_{2}-\mathrm{MeOH}-$ $\mathrm{H}_{2} \mathrm{O}(6: 4: 1,250 \mathrm{~mL})$, and then Sephadex LH-20 (MeOH), respectively, to afford compounds $19(5 \mathrm{mg})$ and $\mathbf{2 0}(7 \mathrm{mg})$.

Zawadskinolide A (3 $\beta$-Acetoxy-1 $\alpha, 15$-dihydroxy-germacra$4 Z, 9 Z$-dien-6 $\beta, 7 \alpha, 11 \alpha H$-12,6-olide) (1): White amorphous powder. $[\alpha]_{\mathrm{D}}^{27}+136.6(c=1.0, \mathrm{MeOH})$; IR $(\mathrm{KBr}) v_{\max } \mathrm{cm}^{-1}: 3470$, $3386(\mathrm{OH}), 1755$ ( $\gamma$-lactone), 1740, $1238(\mathrm{OAc}), 1640(\mathrm{C}=\mathrm{C})$, $1450\left(\mathrm{CH}_{2}\right), 1369\left(\mathrm{CH}_{3}\right), 1218,1031(\mathrm{C}-\mathrm{O}), 960,871,754 ;{ }^{1} \mathrm{H}-$ (400 MHz, CD $\mathrm{OD}$ ) and ${ }^{13} \mathrm{C}-\mathrm{NMR}\left(100 \mathrm{MHz}, \mathrm{CD}_{3} \mathrm{OD}\right)$ : Tables 1 and 3; EI-MS m/z (rel. int., \%): $324[\mathrm{M}]^{+}$(8), $309\left[\mathrm{M}-\mathrm{CH}_{3}\right]^{+}$ (14), $264\left[\mathrm{M}-\mathrm{HOAc}^{+}(7), 246\left[\mathrm{M}-\mathrm{HOAc}^{-} \mathrm{H}_{2} \mathrm{O}\right]^{+}\right.$(9), 233 $\left[\mathrm{M}-\mathrm{HOAc}-\mathrm{CH}_{2} \mathrm{OH}\right]^{+}(35), 218\left[\mathrm{M}-\mathrm{HOAc}-\mathrm{CH}_{2} \mathrm{OH}-\mathrm{CH}_{3}\right]^{+}$ (12), 173 (33), 121 (67), 95 (67), 79 (70), 55 (100); HR-EI-MS $m / z$ : 324.1573. Calcd for $\mathrm{C}_{17} \mathrm{H}_{24} \mathrm{O}_{6}[\mathrm{M}]^{+}: 324.1560$.

Zawadskinolide B [3 $\beta$-Acetoxy-15-hydroxy-germacra1(10)E,4Z-dien-6 $\beta, 7 \alpha, 11 \alpha H$-12,6-olide (15-Hydroxyajanolide A)] (2): Gum. $[\alpha]_{\mathrm{D}}^{29}-81.3\left(c=1.0, \mathrm{CHCl}_{3}\right)$; IR (KBr) $v_{\max }$ $\mathrm{cm}^{-1}: 3461(\mathrm{OH}), 1760$ ( $\gamma$-lactone), 1740, 1249, 1230 (OAc), $1660(\mathrm{C}=\mathrm{C}), 1448\left(\mathrm{CH}_{2}\right), 1371\left(\mathrm{CH}_{3}\right), 1031(\mathrm{C}-\mathrm{O}), 962,885$, 754; ${ }^{1} \mathrm{H}-\left(400 \mathrm{MHz}, \mathrm{CDCl}_{3}\right)$ and ${ }^{13} \mathrm{C}-\mathrm{NMR}\left(100 \mathrm{MHz}, \mathrm{CDCl}_{3}\right)$ : Tables 1 and 3; FAB-MS $m / z: 331[\mathrm{M}+\mathrm{Na}]^{+}$; EI-MS $m / z$ (rel. int., \%): $308[\mathrm{M}]^{+}$(9), $293\left[\mathrm{M}-\mathrm{CH}_{3}\right]^{+}$(3), $248[\mathrm{M}-\mathrm{HOAc}]^{+}$ (15), $217 \quad\left[\mathrm{M}-\mathrm{HOAc}-\mathrm{CH}_{2} \mathrm{OH}\right]^{+} \quad(17), 202 \quad[\mathrm{M}-\mathrm{HOAc}-$ $\left.\mathrm{CH}_{2} \mathrm{OH}-\mathrm{CH}_{3}\right]^{+}$(65), 175 (88), 121 (55), 93 (76), 81 (95), 55 (100); HR-EI-MS m/z: 308.1624. Calcd for $\mathrm{C}_{17} \mathrm{H}_{24} \mathrm{O}_{5}[\mathrm{M}]^{+}$: 308.1630 .

Zawadskinolide C $[3 \beta$-Acetoxy- $1 \beta, 10 \alpha$-epoxy-15-hydroxygermacr-4Z-en-6 $\beta, 7 \alpha, 11 \alpha H$-12,6-olide (15-Hydroxyajanolide A Epoxide)] (3): White amorphous powder. $[\alpha]_{\mathrm{D}}^{30}-59.3(c=1.0$, $\mathrm{CHCl}_{3}$ ); IR (KBr) $v_{\max } \mathrm{cm}^{-1}: 3460(\mathrm{OH}), 1765$ ( $\gamma$-lactone), 1742 (OAc), $1456\left(\mathrm{CH}_{2}\right), 1370\left(\mathrm{CH}_{3}\right), 1242$ (OAc, epoxide), 1212, 1027 (C-O), 963, 879, 755 (epoxide); ${ }^{1} \mathrm{H}-(400 \mathrm{MHz}$, $\left.\mathrm{CD}_{3} \mathrm{OD}\right)$ and ${ }^{13} \mathrm{C}-\mathrm{NMR}\left(100 \mathrm{MHz}, \mathrm{CD}_{3} \mathrm{OD}\right)$ : Tables 1 and 3; CI-MS m/z: $325[\mathrm{M}+\mathrm{H}]^{+}, 307 \quad\left[(\mathrm{M}+\mathrm{H})-\mathrm{H}_{2} \mathrm{O}\right]^{+}, 283$ $\left[(\mathrm{M}+\mathrm{H})-\mathrm{CH}_{2} \mathrm{CO}\right]^{+}, 265[(\mathrm{M}+\mathrm{H})-\mathrm{HOAc}]^{+}, 247[(\mathrm{M}+\mathrm{H})-$ $\left.\mathrm{HOAc}-\mathrm{H}_{2} \mathrm{O}\right]^{+}, 229\left[(\mathrm{M}+\mathrm{H})-\mathrm{HOAc}-2 \mathrm{H}_{2} \mathrm{O}\right]^{+}, 219[(\mathrm{M}+\mathrm{H})-$ $\left.\mathrm{HOAc}-\mathrm{H}_{2} \mathrm{O}-\mathrm{CO}\right]^{+}, 201\left[(\mathrm{M}+\mathrm{H})-\mathrm{HOAc}-2 \mathrm{H}_{2} \mathrm{O}-\mathrm{CO}\right]^{+}, 173$ $\left[(\mathrm{M}+\mathrm{H})-\mathrm{HOAc}-2 \mathrm{H}_{2} \mathrm{O}-2 \mathrm{CO}\right]^{+}$; HR-CI-MS $\mathrm{m} / \mathrm{z}$ : 325.1653.
Calcd for $\mathrm{C}_{17} \mathrm{H}_{25} \mathrm{O}_{6}[\mathrm{M}+\mathrm{H}]^{+}: 325.1657$.

Zawadskinolide D $\quad[1 \beta, 3 \beta, 15$-Trihydroxy-germacra4Z,10(14)-dien-6 $\beta, 7 \alpha, 11 \alpha H$-12,6-olide] (4): White amorphous powder. $[\alpha]_{\mathrm{D}}^{28}-17.2\left(c=0.2, \mathrm{CHCl}_{3}\right)$; IR $(\mathrm{KBr}) v_{\max } \mathrm{cm}^{-1}: 3388$ (OH) 1749 ( $\gamma$-lactone), $1647(\mathrm{C}=\mathrm{C}), 1456\left(\mathrm{CH}_{2}\right), 1380\left(\mathrm{CH}_{3}\right)$, 1187, 1039, 980, 754; ${ }^{1} \mathrm{H}-\left(500 \mathrm{MHz}, \mathrm{CDCl}_{3}\right)$ and ${ }^{13} \mathrm{C}-\mathrm{NMR}$ $\left(125 \mathrm{MHz}, \mathrm{CDCl}_{3}\right)$ : Tables 2 and 3; FAB-MS m/z: 305 $[\mathrm{M}+\mathrm{Na}]^{+}$; HR-FAB-MS $m / z$ : 305.1365. Calcd for $\mathrm{C}_{15} \mathrm{H}_{22} \mathrm{O}_{5} \mathrm{Na}$ $[\mathrm{M}+\mathrm{Na}]^{+}: 305.1358$.

Zawadskinolide E [15-Acetoxy-1 $\beta, 3 \beta$-dihydroxy-germacra$4 Z, 10(14)$-dien-6 $\beta, 7 \alpha, 11 \alpha H$-12,6-olide] (5): White amorphous powder. $[\alpha]_{\mathrm{D}}^{27}-47.5\left(c=1.0, \mathrm{CHCl}_{3}\right)$; IR $(\mathrm{KBr}) v_{\max } \mathrm{cm}^{-1}$ : $3419(\mathrm{OH}), 1749$ ( $\gamma$-lactone, OAc), $1647(\mathrm{C}=\mathrm{C}), 1455\left(\mathrm{CH}_{2}\right)$, $1380\left(\mathrm{CH}_{3}\right), 1240$ (OAc), 1038 (C-O), 987, 917, 753; ${ }^{1} \mathrm{H}-$ $\left(400 \mathrm{MHz}, \mathrm{CDCl}_{3}\right)$ and ${ }^{13} \mathrm{C}-\mathrm{NMR}\left(100 \mathrm{MHz}, \mathrm{CDCl}_{3}\right)$ : Tables 2 and 3; CI-MS m/z: $325[\mathrm{M}+\mathrm{H}]^{+}, 307\left[(\mathrm{M}+\mathrm{H})-\mathrm{H}_{2} \mathrm{O}\right]^{+}$, $289\left[(\mathrm{M}+\mathrm{H})-2 \mathrm{H}_{2} \mathrm{O}\right]^{+}, 265[(\mathrm{M}+\mathrm{H})-\mathrm{HOAc}]^{+}, 247[(\mathrm{M}+\mathrm{H})-$ $\left.\mathrm{HOAc}-\mathrm{H}_{2} \mathrm{O}\right]^{+}, 229\left[(\mathrm{M}+\mathrm{H})-\mathrm{HOAc}-2 \mathrm{H}_{2} \mathrm{O}\right]^{+}, 201[(\mathrm{M}+\mathrm{H})-$ $\left.\mathrm{HOAc}-2 \mathrm{H}_{2} \mathrm{O}-\mathrm{CO}\right]^{+}, \quad 173 \quad\left[(\mathrm{M}+\mathrm{H})-\mathrm{HOAc}-2 \mathrm{H}_{2} \mathrm{O}-2 \mathrm{CO}\right]^{+}$; HR-CI-MS $m / z:$ 325.1653. Calcd for $\mathrm{C}_{17} \mathrm{H}_{25} \mathrm{O}_{6}[\mathrm{M}+\mathrm{H}]^{+}$: 325.1651 .

Zawadskinolide F [3 $\beta$-Acetoxy-1 $\beta, 15$-dihydroxy-germacra$4 Z, 10(14)$-dien-6 $\beta, 7 \alpha, 11 \alpha H$-12,6-olide] (6): White amorphous powder. $[\alpha]_{\mathrm{D}}^{27}+24.2(c=0.5, \mathrm{MeOH})$; IR $(\mathrm{KBr}) v_{\max } \mathrm{cm}^{-1}$ : $3409(\mathrm{OH}), 1743$ ( $\gamma$-lactone, OAc), 1239 (OAc), 1650 $(\mathrm{C}=\mathrm{C}), 1444\left(\mathrm{CH}_{2}\right), 1371\left(\mathrm{CH}_{3}\right), 1022(\mathrm{C}-\mathrm{O}), 963,756$; ${ }^{1} \mathrm{H}-\left(400 \mathrm{MHz}, \mathrm{CD}_{3} \mathrm{OD}\right)$ and ${ }^{13} \mathrm{C}-\mathrm{NMR}\left(100 \mathrm{MHz}, \mathrm{CD}_{3} \mathrm{OD}\right)$ : Tables 2 and 3; CI-MS $m / z: 325[\mathrm{M}+\mathrm{H}]^{+}, 307[(\mathrm{M}+\mathrm{H})-$ $\left.\mathrm{H}_{2} \mathrm{O}\right]^{+}, 265[(\mathrm{M}+\mathrm{H})-\mathrm{HOAc}]^{+}, 247\left[(\mathrm{M}+\mathrm{H})-\mathrm{HOAc}-\mathrm{H}_{2} \mathrm{O}\right]^{+}$, $229\left[(\mathrm{M}+\mathrm{H})-\mathrm{HOAc}-2 \mathrm{H}_{2} \mathrm{O}\right]^{+}, 219\left[(\mathrm{M}+\mathrm{H})-\mathrm{HOAc}-\mathrm{H}_{2} \mathrm{O}-\right.$ $\mathrm{CO}^{+}, \quad 201\left[(\mathrm{M}+\mathrm{H})-\mathrm{HOAc}-2 \mathrm{H}_{2} \mathrm{O}-\mathrm{CO}\right]^{+}, \quad 173 \quad[(\mathrm{M}+\mathrm{H})-$ $\mathrm{HOAc}-2 \mathrm{H}_{2} \mathrm{O}-2 \mathrm{CO}^{+}$; HR-CI-MS $\mathrm{m} / z$ : 323.1495. Calcd for $\mathrm{C}_{17} \mathrm{H}_{23} \mathrm{O}_{6}[\mathrm{M}-\mathrm{H}]^{+}: 323.1493$.

Chrysantiloboside $(1 \beta, 4 \beta, 12$-Trihydroxy-eudesm-7-ene 1 - $O$ $\beta$-D-Glucopyranoside) (7): White amorphous powder. $[\alpha]_{\mathrm{D}}^{19}$ $-30.1(c=0.7, \mathrm{MeOH})$; IR $(\mathrm{KBr}) v_{\max } \mathrm{cm}^{-1}: 3432(\mathrm{OH}), 1636$ $(\mathrm{C}=\mathrm{C}), 1383\left(\mathrm{CH}_{3}\right), 1075,1025$ (glycosidic $\left.\mathrm{C}-\mathrm{O}\right) ;{ }^{1} \mathrm{H}-\mathrm{NMR}$ $\left(400 \mathrm{MHz}, \mathrm{CD}_{3} \mathrm{OD}\right) \delta: 1.01\left(3 \mathrm{H}, \mathrm{s}, 14-\mathrm{CH}_{3}\right), 1.03(3 \mathrm{H}, \mathrm{d}$, $\left.J=6.9 \mathrm{~Hz}, 13-\mathrm{CH}_{3}\right), 1.14\left(3 \mathrm{H}, \mathrm{s}, 15-\mathrm{CH}_{3}\right), 1.29(1 \mathrm{H}, \mathrm{dd}, J=5.2$, $10.2 \mathrm{~Hz}, \mathrm{H}-5), 1.47$ (1H, ddd, $J=3.6,14.0,13.8 \mathrm{~Hz}, \mathrm{H}-3 \mathrm{a}), 1.69$ $(1 \mathrm{H}, \mathrm{dq}, J=3.4,12.5 \mathrm{~Hz}, \mathrm{H}-2 \mathrm{a}), 1.75(1 \mathrm{H}, \mathrm{dt}, J=3.0,13.9 \mathrm{~Hz}$, $\mathrm{H}-3 \mathrm{~b}), 1.86$ (1H, ddd, J=3.2, 10.9, $12.2 \mathrm{~Hz}, \mathrm{H}-2 \mathrm{~b}), 1.89(1 \mathrm{H}$, brd, $J=15.0 \mathrm{~Hz}, \mathrm{H}-9 \mathrm{a}), 2.00-2.12(2 \mathrm{H}, \mathrm{m}, \mathrm{H}-6), 2.14(1 \mathrm{H}$, $\mathrm{dd}, J=5.2,15.0 \mathrm{~Hz}, \mathrm{H}-9 \mathrm{~b}), 2.22(1 \mathrm{H}, \mathrm{q}, J=7.0 \mathrm{~Hz}, \mathrm{H}-11)$, $3.15\left(1 \mathrm{H}, \mathrm{t}, J=8.6 \mathrm{~Hz}, \mathrm{H}-2^{\prime}\right), 3.23\left(1 \mathrm{H}, \mathrm{m}, \mathrm{H}-5^{\prime}\right), 3.30(1 \mathrm{H}, \mathrm{t}$, $\left.J=8.5 \mathrm{~Hz}, \mathrm{H}-4^{\prime}\right), 3.34\left(1 \mathrm{H}, \mathrm{t}, J=8.9 \mathrm{~Hz}, \mathrm{H}-3^{\prime}\right), 3.39(1 \mathrm{H}, \mathrm{dd}$, $J=7.6,10.8 \mathrm{~Hz}, \mathrm{H}-12 \mathrm{a}), 3.40(1 \mathrm{H}, \mathrm{dd}, J=4.4,12.0 \mathrm{~Hz}, \mathrm{H}-1)$, $3.56(1 \mathrm{H}, \mathrm{dd}, J=6.7,10.8 \mathrm{~Hz}, \mathrm{H}-12 \mathrm{~b}), 3.65(1 \mathrm{H}, \mathrm{dd}, J=5.6$, $\left.11.8 \mathrm{~Hz}, \mathrm{H}-6^{\prime} \mathrm{a}\right), 3.85$ (1H, dd, $\left.J=2.1,11.8 \mathrm{~Hz}, \mathrm{H}-6^{\prime} \mathrm{b}\right), 4.31(1 \mathrm{H}$, d, $\left.J=7.8 \mathrm{~Hz}, \mathrm{H}-1^{\prime}\right), 5.36(1 \mathrm{H}$, brd, $J=4.3 \mathrm{~Hz}, \mathrm{H}-8) ;{ }^{13} \mathrm{C}-\mathrm{NMR}$ (100 MHz, $\left.\mathrm{CD}_{3} \mathrm{OD}\right)$ : Table 3; FAB-MS m/z: $439[\mathrm{M}+\mathrm{Na}]^{+}$.

Acetylation of 4, 5 and 6 Compound 4 (3 mg) was treated with acetic anhydride $(0.3 \mathrm{~mL})$ in pyridine $(0.3 \mathrm{~mL})$ at room temperature overnight. Usual workup gave a product 4a $[1 \beta, 3 \beta, 15$-triacetoxy-germacra-4Z,10(14)-dien-6 $\beta, 7 \alpha, 11 \alpha H$ 12,6 -olide] $(2 \mathrm{mg})$ as an amorphous powder. IR (KBr) $v_{\max }$ $\mathrm{cm}^{-1}: 1772$ ( $\gamma$-lactone), 1740, 1236 (OAc), $1650(\mathrm{C}=\mathrm{C}), 1454$ $\left(\mathrm{CH}_{2}\right), 1373\left(\mathrm{CH}_{3}\right), 1026,979,756 ;{ }^{1} \mathrm{H}-\mathrm{NMR} \quad(500 \mathrm{MHz}$, $\left.\mathrm{CDCl}_{3}\right) \delta: 5.21(1 \mathrm{H}, \mathrm{dd}, J=3.4,11.6 \mathrm{~Hz}, \mathrm{H}-1), 2.07(1 \mathrm{H}, \mathrm{m}$, $\mathrm{H}-2 \mathrm{a}), 2.30(1 \mathrm{H}, \mathrm{ddd}, J=2.3,11.6,15.3 \mathrm{~Hz}, \mathrm{H}-2 \mathrm{~b}), 5.52(1 \mathrm{H}$, brd, $J=5.2 \mathrm{~Hz}, \mathrm{H}-3), 5.71(1 \mathrm{H}, \mathrm{d}, J=8.1 \mathrm{~Hz}, \mathrm{H}-5), 5.36(1 \mathrm{H}, \mathrm{d}$, 
$J=8.1 \mathrm{~Hz}, \mathrm{H}-6), 2.58(1 \mathrm{H}, \mathrm{brt}, J=10.7 \mathrm{~Hz}, \mathrm{H}-7), 1.40(1 \mathrm{H}, \mathrm{m}$, H-8a), 1.81 (1H, m, H-8b), 2.00 (1H, m, H-9a), 2.42 (1H, ddd, $J=4.0,8.0,14.8 \mathrm{~Hz}, \mathrm{H}-9 \mathrm{~b}), 2.80$ (1H, dq, $J=7.5,7.9 \mathrm{~Hz}, \mathrm{H}-11)$, $1.11(3 \mathrm{H}, \mathrm{d}, J=7.4 \mathrm{~Hz}, \mathrm{H}-13), 5.26(1 \mathrm{H}, \mathrm{s}, \mathrm{H}-14 \mathrm{a}), 5.34(1 \mathrm{H}, \mathrm{s}$, $\mathrm{H}-14 \mathrm{~b}), 4.41(1 \mathrm{H}, \mathrm{d}, J=13.0 \mathrm{~Hz}, \mathrm{H}-15 \mathrm{a}), 4.59(1 \mathrm{H}, \mathrm{d}, J=13.0 \mathrm{~Hz}$, $\mathrm{H}-15 \mathrm{~b}), \quad 1.97, \quad 1.99,2.01$ (3H each, s, OAc); ${ }^{13} \mathrm{C}-\mathrm{NMR}$ $\left(125 \mathrm{MHz}, \mathrm{CDCl}_{3}\right)$ : Table 3; FAB-MS m/z: $431[\mathrm{M}+\mathrm{Na}]^{+}, 409$ $[\mathrm{M}+\mathrm{H}]^{+}, 349\left[(\mathrm{M}+\mathrm{H})-\mathrm{HOAc}^{+}, 289\left[(\mathrm{M}+\mathrm{H})-2 \mathrm{HOAc}^{+}, 229\right.\right.$ $[(\mathrm{M}+\mathrm{H})-3 \mathrm{HOAc}]^{+}$; HR-FAB-MS $m / z: 431.1682$. Calcd for $\mathrm{C}_{21} \mathrm{H}_{28} \mathrm{O}_{8} \mathrm{Na}[\mathrm{M}+\mathrm{Na}]^{+}:$431.1703. Treatment of 5 (3 mg) and 6 $(2.3 \mathrm{mg})$ in pyridine $(0.5 \mathrm{~mL})$ with acetic anhydride $(0.5 \mathrm{~mL})$ at room temperature overnight, followed by the usual workup, gave the acetate, which was characterized as 4a by TLC and ${ }^{1} \mathrm{H}-\mathrm{NMR}$ with the authentic sample.

Cell Culture RAW 264.7 murine macrophages were obtained from the American Type Culture Collection (U.S.A.). These cells were maintained at sub-confluence in a $95 \%$ air and $5 \% \mathrm{CO}_{2}$ humidified atmosphere at $37^{\circ} \mathrm{C}$. The medium used for routine subculture was Dulbecco's modified Eagle's medium (DMEM) supplemented with $10 \%$ fetal bovine serum (FBS), penicillin (100 units $/ \mathrm{mL})$ and streptomycin $(100 \mu \mathrm{g} / \mathrm{mL})$.

MTT Assay for Cell Viability The effects of the isolates $(\mathbf{1}-\mathbf{6}, \mathbf{8}-\mathbf{1 8}, \mathbf{2 0})$ or vehicle on cell viability were measured by MTT assay. Briefly, RAW 264.7 cells were plated at a density of $1 \times 10^{4}$ per well in a 96 -well plate, and incubated at $37^{\circ} \mathrm{C}$ for $24 \mathrm{~h}$. The cells were treated with various concentrations of the isolates or vehicle alone for $2 \mathrm{~h}$ prior to LPS $(1 \mu \mathrm{g} /$ $\mathrm{mL}$ ) stimulation and then incubated at $37^{\circ} \mathrm{C}$ for an additional $18 \mathrm{~h}$. After incubation for $18 \mathrm{~h}, 100 \mu \mathrm{L}$ of MTT $(0.5 \mathrm{mg} / \mathrm{mL}$ in saline) solution was added to each well and incubated under the same conditions for another $2 \mathrm{~h}$. Mitochondrial succinate dehydrogenase in live cells converted the MTT into visible formazan crystals during incubation. The formazan crystals were then solubilized in DMSO and the absorbance was measured at $595 \mathrm{~nm}$ in an enzyme-linked immunosorbent assay (Molecular Devices, Emax, Sunnyvale, CA, U.S.A.). Relative cell viability was calculated compared with the absorbance of the untreated control group. All experiments were performed in triplicate.

NO Determination Using the Griess reaction method, the inhibitory effect on NO production in murine macrophage-like RAW 264.7 cells was evaluated in the medium as an indicator of nitric oxide production, as described previously. ${ }^{39)}$ In brief, $1 \times 10^{5}$ RAW 264.7 cells were plated in 24 -well plates, incubated for $24 \mathrm{~h}$ and pre-treated with different concentrations of the isolates $(\mathbf{1}-\mathbf{6}, \mathbf{8}-\mathbf{1 8}, \mathbf{2 0})$ or vehicle for another $2 \mathrm{~h}$, then challenged with LPS $(1 \mu \mathrm{g} / \mathrm{mL})$ for an additional $18 \mathrm{~h}$. Equal volumes of cultured medium and Griess reagent $(1 \%$ sulfanilamide in 5\% phosphoric acid and $0.1 \%$ naphtylethylenediamine dihydrochloride in distilled water) were mixed, the absorbance at $540 \mathrm{~nm}$ was determined with a microplate reader (Molecular Devices, Emax, Sunnyvale, CA, U.S.A.), and the absorption coefficient was calibrated using a sodium nitrite solution standard. For this experiment, 2-amino-5,6dihydro-6-methyl-4H-1,3-thiazine (AMT) was used as a positive control.

Data Analysis The results were expressed as mean \pm standard deviation (S.D.). Analysis of variance (ANOVA) with Dunnett's $t$-test was used for the statistical analysis of multiple comparisons of data. $p$-Values less than 0.05 were considered statistically significant. [ $\left.{ }^{*} p<0.05 ; * * p<0.01 ; * * * p<0.001\right]$
Acknowledgements The work was financially supported by the second phase of the Brain Korea 21 Program in 2010. The authors are grateful to Prof. Y.-B. Suh for identification of the plant materials. CI-MS data were obtained from the National Center for Inter-University Research Facilities, Seoul National University.

\section{References}

1) Lee T. B., "Illustrated Flora of Korea," Hyangmoonsa, Seoul, 1989.

2) Bae K.-H., "The medicinal plants of Korea," Kyo-Hak Publishing Co., Ltd., Seoul, 2000.

3) Rahman Md A. A., Cho S.-C., Song J.-K., Mun H.-T., Moon S.-S., Planta Med., 73, 1089-1094 (2007).

4) Jang D. S., Park K. H., Choi S. W., Nam S. H., Yang M. S., Agric. Chem. Biotechnol., 40, 85-88 (1997).

5) Rahman Md A. A., Moon S.-S., Arch. Pharm. Res., 30, 1374-1379 (2007).

6) Singh R. P., Agrawal P., Yim D.-S., Agarwal C., Agarwal R., Carcinogenesis, 26, 845-854 (2005).

7) Han S.-H., Sung K.-H., Yim D.-S., Lee S.-Y., Lee C.-K., Ha N.-J., Kim K.-J., Arch. Pharm. Res., 25, 170-177 (2002).

8) Byun Y. H., Shin S.-W., Nat. Prod. Sci., 14, 138-142 (2008).

9) Tsevegsuren N., Fujimoto K., Christie W. W., Endo Y., Lipids, 38, $573-578$ (2003).

10) Jang D. S., Park K. H., Kim H. M., Hong D. H., Chun H. K., Kho Y. H., Yang M. S., Korean J. Pharmacogn., 29, 243-247 (1998).

11) Jang D. S., Park K. H., Ko H. L., Lee H. S., Kwon B. M., Yang M. S., Korean J. Pharmacogn., 30, 74-78 (1999).

12) Jang D. S., Kwon B. M., Yang M. S., Korean J. Pharmacogn., 30, 70-73 (1999).

13) Seo J. Y., Lim S. S., Park J. A., Lim J.-S., Kim H. J., Kang H. J., Park-Yoon J. H., Kim J.-S., Nutr. Res. Pract., 4, 93-98 (2010).

14) Youm H.-S., Choi S.-I., Heo T.-R., J. Biotechnol., 136S, S727-S728 (2008).

15) Kupchan S. M., Maruyama M., Hemingway R. J., Hemingway J. C., Shibuya S., Fujita T., J. Org. Chem., 38, 2189-2196 (1973).

16) Herz W., de Groote R., Murari R., Blount J. F., J. Org. Chem., 43, $3559-3564$ (1978).

17) Herz W., Govindan S. V., Kumar N., Phytochemistry, 20, $1343-$ 1347 (1981).

18) Marco J. A., Sanz J. F., Jakupovic J., Huneck S., Tetrahedron, 46, 6931-6938 (1990).

19) Pregosin P. S., Randall E. W., McMurry T. B. H., J. Chem. Soc., Perkin Trans. 1, 1972, 299-301 (1972).

20) Mahmoud A. A., Ahmed A. A., Iinuma M., Tanaka T., Phytochemistry, 36, 393-398 (1994).

21) Herz W., Wahlberg I., J. Org. Chem., 38, 2485-2489 (1973).

22) Breton J. L., Camps F., Coll J., Eguren L., Gavin J. A., Gonzalez A. G., Martorell X., Miravitlies C., Molins E., Torramilans J., Tetrahedron, 41, 3141-3146 (1985).

23) Adekenov S. M., Kulyjasov A. T., Raldugin V. A., Bagryanskaya I. Yu., Gatilov Yu. V., Shakirov M. M., Russ. Chem. Bull., 47, 169172 (1998).

24) Cardona L., García B., Muñoz M. C., Navarro F. I., Pedro J. R., Liebigs Annal./Recueli, 1997, 527-532.

25) Kulyyasov A. T. Edil'baeva. T. T., Turdybekov K. M., Raldugin V. A., Shakirov M. M., Adekenov S. M., Chem. Nat. Compd., 35, 55-60 (1999).

26) Baruah N. C., Sharma R. P., Madhusudaanan K. P., Thyagarajan G., Herz W., Murari R., J. Org. Chem., 44, 1831-1835 (1979).

27) González A. G., Bermejo J., Mansilla H., Galindo A., Amaro J. M., Massanet G. M., J. Chem. Soc., Perkin Trans. 1, 1978, 1243-1246 (1978).

28) Lee I. K., Kim K. H., Ryu S. Y., Lee K. R., Heterocycles, 78, $2827-2835$ (2009).

29) Kim J. S., Shim S. H., Xu Y. N., Kang S. S., Son K. H., Chang H. 
W., Kim H. P., Bae K.-H., Chem. Pharm. Bull., 52, 714-717 (2004).

30) Moretti C., Sauvain M., Lavaud C., Massiot G., Bravo J.-A., Muñoz V., J. Nat. Prod., 61, 1390-1393 (1998).

31) Kim J. S., Kim Y. J., Lee J. Y., Kang S. S., Korean J. Pharmacogn., 39, 28-36 (2008).

32) Kupchan S. M., Sigel C. W., Hemingway R. J., Knox J. R., Udayamurthy M. S., Tetrahedron, 25, 1603-1615 (1969).

33) Kim J. S., Kim J. C., Shim S. H., Lee E. J., Jin W.-Y., Bae K.-H., Son K. H., Kim H. P., Kang S. S., Chang H. W., Arch. Pharm. Res., 29, 617-623 (2006).

34) Shin K. H., Kang S. S., Seo E. A., Shin S. W., Arch. Pharm. Res.,
18, 65-68 (1995).

35) Kitajima J., Ishikawa T., Tanaka Y., Ida Y., Chem. Pharm. Bull., 47, 988-992 (1999).

36) Kim J. S., Yean M. H., Lee J.-H., Kang S. S., Nat. Prod. Sci., 16, 15-19 (2010).

37) Miyase T., Ueno A., Takizawa N., Kobayashi H., Oguchi H., Chem. Pharm. Bull., 36, 2475-2484 (1988).

38) Noiarsa P., Yu Q., Matsunami K., Otsuka H., Ruchirawat S., Kanchanapoon T., J. Nat. Med., 61, 406-409 (2007).

39) Shin E. M., Zhou H. Y., Xu G. H., Lee S. H., Merfort I., Kim Y. S., Eur. J. Pharmacol., 627, 318-324 (2010). 